\title{
Roberto \\ Cerón \\ Una aproximación a la escrituración e interpretación del contrato colectivo de trabajo
}

Reyes

Universidad

de Chile

roberto.ceron@derecho.uchile.cl

Recibido: 12.10 .21

Aceptado: 03.12.21

\section{Writing and interpreting a collective labor agreement: an aproximation}

Resumen: Se examinan dos aspectos vinculados al contrato colectivo de trabajo. Primero, las formalidades que envuelven a dicha convención, es decir, suescrituracióny registro, conel objeto de identificar su tipo y los efectos derivados de su incumplimiento. Segundo, la interpretación de este acto jurídico, punto donde también se abordan, a modo de necesarias cuestiones previas, las siguientes materias: i) aspectos básicos de hermenéutica del derecho; ii) la naturaleza jurídica del contrato colectivo de trabajo; y iii) la aplicación supletoria del derecho civil en el derecho del trabajo. Ello desemboca en el análisis relativo a la utilización de las normas de interpretación contractual del Código Civil y el significado dado por la Dirección del Trabajo y los tribunales de justicia a algunas de estas disposiciones.

Palabras clave: contrato colectivo de trabajo; formalidades; derecho civil, Código Civil; Código del Trabajo; interpretación contractual.
Abstract: We examine two elements related to the collective labor agreement. First is the formalities that involve this contract: its deed and registration, which let us identify its kind and the effects derived from its breach. Second, the interpretation of this legal act, where we also discuss the following aspects as preliminary issues. First, the essential elements of legal hermeneutics. Second, the legal nature of the collective labor agreement. And third, the suppletory application of civil law in the labor law. The latter results in analyzing the Civil Code's contract interpretation laws and the meaning given to some of these provisions by the Labor's Office and the courts of justice.

Keywords: colective labor agreement; formalities; civil law; Civil Code; Labour Code; contractual interpretation. 
La ley $\mathrm{N}^{\circ}$ 20.940, de 2016, de reforma al derecho colectivo del trabajo, incorporó al CdT el art. 320 inc. $1^{\circ}$, que se refiere al instrumento colectivo, definiéndolo como "la convención celebrada entre empleadores y trabajadores con el objeto de establecer condiciones comunes de trabajo y remuneraciones $u$ otros beneficios en especie o en dinero, por un tiempo determinado, de conformidad a las reglas previstas en este Libro [el IV, sobre negociación colectiva]". A juicio de Irureta, esta tipología contractual laboral es amplia y genérica, de forma tal que bajo su alero quedan comprendidas, en una relación de género a especie, las siguientes figuras: el contrato colectivo, el convenio colectivo, el fallo arbitral y, se quiera o no, el acuerdo del grupo negociador (Irureta, 2016, pp. 14 y 16).

De su lado, el art. 6. inc. $3^{\circ}$ del CdT define al contrato colectivo como "el celebrado por uno o más empleadores con una o más organizaciones sindicales o con trabajadores que se unan para negociar colectivamente, o con unos y otros, con el objeto de establecer condiciones comunes de trabajo y de remuneraciones por un tiempo determinado". El presente trabajo apunta a mostrar y analizar, a modo de primera aproximación, dos materias asociadas a esta convención celebrada entre una empresa y un sindicato: i) su escrituración y registro (art. 320 inc. $3^{\circ}$ del CdT) y ii) la interpretación de este acto jurídico. Ambos aspectos han sido escasamente estudiados por la doctrina nacional reciente, cuestión que, se piensa, valida una incursión en estos tópicos.

Para adentrarse en los puntos ya descritos se recurrirá a la legislación - vigente e histórica-, la doctrina y la jurisprudencia. Igualmente, se acudirá, cuando corresponda, a fuentes de derecho extranjeras, principalmente para ilustrar las situaciones que acá se comentan. De ello fluye que la perspectiva de la reflexión sea eminentemente dogmática, método que se complementa, sobre todo en la primera parte del texto, con el histórico-legislativo.

El artículo se estructura del modo que sigue. Primero se desarrollan las formalidades que envuelven al contrato colectivo de trabajo, es decir, su escrituración y registro, oportunidad donde se ofrecerá una propuesta en torno al tipo de formalidad de ambas exigencias y los efectos derivados de su incumplimiento. Después se pasa a la interpretación de este instrumento colectivo, donde se abordan ciertos aspectos básicos de hermenéutica del derecho; la naturaleza jurídica de dicho contrato; y la aplicación supletoria del derecho civil en el ámbito laboral. Lo anterior permite, en la última parte de la contribución, interiorizarse en un análisis acerca de la utilización de las normas de interpretación contractual del Código Civil y el significado dado por la Dirección del Trabajo y los tribunales de justicia a algunas de estas reglas, específicamente las ubicadas en los artículos 1560, 1561 y 1564 inc. 2. Finalmente, se presentan las conclusiones de rigor.

\section{Escrituración del contrato colectivo de trabajo}

De acuerdo con el art. 320 inc. $3^{\circ}$ del CdT, el contrato colectivo de trabajo "deberá constar por escrito y registrarse en la Inspección del Trabajo dentro de los cincos días siguientes a su suscripción". Ambos requisitos sitúan a este acto jurídico fuera de la consensualidad propia del contrato individual de trabajo (Irureta, 2016, p. 17), acercándolo más bien a uno afecto a ciertas formalidades ${ }^{1}$.

\footnotetext{
${ }^{1}$ En expresión de Corral las formalidades son "todos los requisitos externos añadidos a la expresión de voluntad que, para diferentes fines, la ley establece respecto de determinados actos jurídicos" (2018, p. 612).
} 
Estas dos exigencias se remontan a los orígenes de la legislación laboral chilena. Sin entrar en detalles, desde el CdT de 1931 que estas formalidades envuelven al contrato colectivo; así se desprende del art. 19 del texto legal recién citado 2 . Igual cosa sucede con el art. 30 inc. $2^{\circ}$ e inc. $3^{\circ}$ del $\mathrm{DL} \mathrm{N}^{\circ} 2.758^{3}$, conocido también como "Plan Laboral", disposición que en virtud de la ley $\mathrm{N}^{\circ}$ 18.620 de 1987 se incorpora, en idénticos términos, al art. 315 inc. $2^{\circ}$ del CdT. Finalmente, los incisos $3^{\circ}$ y $4^{\circ}$ del art. 120 de la ley $\mathrm{N}^{\circ} 19.069^{4}$, de 1991, consagran tales formalidades, normativa que se fijó en el art. 344 inc. $3^{\circ}$ del CdT, a través de DFL № 1 de 1994.

\subsection{La escrituración del contrato colectivo propiamente} tal

La escrituración de este contrato es una solemnidad - especie de formalidad - constitutiva, pues a través de ella se expresa el concurso de voluntades de las partes que celebran este acto jurídico (empresa y sindicato), al punto que, si se omite tal exigencia, simplemente no hay consentimiento (Corral, 2018, p. 613; Barcia, 2010, p. 102; López, 2010, p. 98; Vial, 2006, pp. 215-216; Ducci, 2006, pp. 317-319; Alessandri, Somarriva y Vodanovic; 2005, p. 312); al tenor del artículo 1443 del CC, se está frente a un contrato "solemne" pues "está sujeto a la observancia de ciertas formalidades especiales, de manera que sin ellas no produce ningún efecto civil", efecto drástico que se analizará oportunamente. En general, la doctrina laboral reciente no ha prestado una debida atención a los alcances de esta solemnidad, limitándose a una descripción general de aquella en los manuales de estilo (Lizama y Riquelme, 2021, p. 205;
Gamonal, 2020, p. 326; Lanata, 2018, p. 247; Walker y Arellano, 2014, p. 723; Humeres, 2005, p. 230; Macchiavello, 1989, pp. 394-395); también abordándola en estudios sobre contratación colectiva (Irureta, 2016, pp. 16-17) o revisándola circunstancialmente a la hora de desarrollar ciertas temáticas (Ogalde, 2016, p. 182).

Más allá fueron algunos comentaristas del CdT de 1931, quienes sí se refirieron a este punto. Para ellos la escrituración es una solemnidad constitutiva (Walker, p. 1941, p. 211; Escribar, 1944, p. 450; Gaete, 1960, p. 258; indirectamente Humeres, 1960 , p. 45; y entre la doctrina actual Macchiavello, 1989, p. 394) que caracteriza al contrato colectivo y lo diferencia del contrato individual, de modo que si el primero no se escritura o es meramente verbal adolecería de nulidad absoluta (Pérez, 1937, p. 67; Escribar, 1944, p. 450; Gaete, 1960, p. 258; y también Macchiavello, 1989, p. 394). Sanción civil que se explica porque la escrituración es un elemento consustancial a esta especie de contrato, es decir, intrínseco a su naturaleza ${ }^{5}$ (Ducci, 2006, pp. 317; Barcia, 2010, p. 103; López, 2010, p. 99). Cierto autor, más tajante, postula que la no escrituración acarrea la nulidad de pleno derecho del acto sin necesidad alguna de declaración judicial (Corral, 2018, pp. 614-615).

Las razones esgrimidas por algunos intérpretes del CdT de 1931 para explicar este requisito del contrato colectivo refieren a lo numerosa de la clase obrera y lo cuantioso de los intereses en juego (Humeres, 1960, p. 44), y la particularidad de esta convención, asimilable a una "ley no parlamentaria"6 (Escribar, 1944, p. 450). No obstante la importancia de aquellas consideraciones,

\footnotetext{
2 "El contrato colectivo se extenderá en tres ejemplares, uno de los cuales se remitirá al Inspector del Trabajo respectivo" (las cursivas son mías). El texto en Ruiz de Gamboa y Díaz, 1942, p. 36.

${ }^{3}$ A propósito del contrato colectivo los incisos en cuestión señalaban: "Si dicho acuerdo se produjere, sus estipulaciones constituirán el contrato colectivo y deberán constar por escrito.- Copia de este contrato deberá enviarse a la Inspección del Trabajo dentro de los 5 días siguientes a su suscripción" (las cursivas son mías). El texto en Díaz, 1982, p. 164.

4 "El contrato colectivo deberá constar por escrito.- Copia de este contrato deberá enviarse a la Inspección del Trabajo dentro de los cincos días siguientes a su suscripción" (las cursivas son mías). El texto ha sido recuperado de: https://www.bcn.cl/leychile/ navegar?idNorma=30436 [fecha de consulta: 5 de abril de 2021].

${ }^{5}$ Véanse los arts. 1681 y 1682 del CC.

${ }^{6}$ En el apartado de interpretación del contrato colectivo de trabajo se revisará este aspecto.
} 
pareciera ser que los motivos de esta solemnidad apuntan a evitar ulteriores disputas sobre el contenido del contrato colectivo (Despax, 1966, p. 250; Irureta, 2016, p. 17), porque la forma escrita garantiza y facilita su conocimiento (Cruz, 2015, p. 521; Martín, RodríguezSañudo y García, 2016, p. 395) y, por añadidura, lo dota de certeza jurídica al tornar indudable su existencia (Cruz, 2015, p. 521).

A propósito de la interpretación de cláusulas del contrato colectivo y la discusión sobre las formalidades de los pactos de horas de trabajo sindical, la jurisprudencia judicial ha resaltado el carácter solemne del mismo, identificándolo casi exclusivamente con su escrituración. Se sostiene que a través de este último atributo se fijan las obligaciones de las partes y se excluye la existencia de cláusulas tácitas; ${ }^{7}$ que la formalidad en asunto se explicaría por la naturaleza colectiva de este acto jurídico, que supone el consentimiento - eventual- de partes "plurales" (empresas y sindicatos) y, además, su posible extensión a sujetos que ni siquiera participaron en su gestación (extensión de beneficios); ; otros pronunciamientos hablan de solemnidades del contrato colectivo, sin entrar en mayores detalles ${ }^{9}$. Por su parte, la jurisprudencia administrativa, pronunciándose sobre la improcedencia de las cláusulas tácitas en los contratos colectivos, sostiene idéntico predicamento sobre la escrituración, en tanto el acto jurídico en cuestión "para que nazca a la vida del derecho y, por consiguiente, produzca todos los efectos que le son propios, requiere necesariamente de una formalidad especial, cual es la escrituración del documento"10.

Si se mira la legislación extranjera ${ }^{11}$, la escrituración del contrato colectivo es vista como una solemnidad constitutiva. En España, el ET menciona como requisito de validez del convenio colectivo, asimilable - en términos generales - al contrato colectivo chileno, la forma escrita, so pena de nulidad ${ }^{12}$; en términos semejantes a la norma ibérica se ubica la francesa ${ }^{13}$. A diferencia del precepto chileno, ambas se refieren a la sanción de nulidad. Esto es significativo, ya que, frente a controversias de este tipo, el juzgador laboral podría aplicar directamente la regla especial, sin necesidad de recurrir supletoriamente a la legislación civil, como debería ocurrir en nuestro caso. Situación no problemática en sí misma, pero que conlleva un esfuerzo argumentativo tendente a superar las reticencias que, a veces, despierta la aplicación del derecho civil en el derecho del trabajo. En el plano internacional, la forma escrita también es sugerida en la Recomendación N 91 de la OIT, sobre los contratos colectivos $^{14}$.

\subsection{El registro en la Inspección del Trabajo}

El registro en la Inspección del Trabajo dentro de los cincos días siguientes a su suscripción corresponde a la segunda formalidad del contrato colectivo de trabajo. Una primera interrogante que se debe dilucidar es la identificación de su naturaleza, punto en que la doctrina

\footnotetext{
${ }^{7}$ CA de San Miguel, Rol N 362-2017 (Reforma Laboral), de 07/12/2017, considerando séptimo; $1^{\circ}$ JLT de Santiago, RIT O-6865-2016, de 21/04/2017, considerando octavo; CA de Santiago, Rol № 1645-2013 (Reforma Laboral), de 16/04/2014; y CA de Santiago, Rol N 120-2012 (Reforma Laboral), de 17/08/2012, considerando noveno.

${ }^{8}$ CS, RUJ (rechazado) Rol No 4187-2013, de 14/10/2013, considerando sexto.

9 JLT de Talca, RIT S-1-2020, de 22/03/2021.

${ }^{10}$ Ord. No 3787, de 06/10/2014. En igual sentido Ord. N²996, de 03/06/2016.

${ }^{11}$ El uso que aquí se le da a la legislación extranjera es sencillo, pues con ello se apunta a "la ilustración de los problemas, en la búsqueda de argumentos en casos concretos y en la propuesta de alternativas" (Ferrante, 2016, p.605).

${ }^{12}$ Art. 90 número 1 del ET "[l]os convenios colectivos a que se refiere esta ley han de formalizarse por escrito, bajo sanción de nulidad".

${ }^{13}$ Article L2231-3: "La convention ou l'accord est, à peine de nullité, un acte écrit”; cuya traducción libre sería: "La convención o acuerdo es, bajo pena de nulidad, un acto escrito". Recuperado de: https://www.legifrance.gouv.fr/codes/article_lc/LEGIARTI000006901672/ [fecha de consulta: 15 de abril de 2021].

${ }_{14}$ La recomendación en: https://www.ilo.org/dyn/normlex/es/f?p=NORMLEXPUB:12100:0::NO::P12100_ILO_CODE:R091[fecha de consulta: 20 de abril de 2021].
} 
laboral reciente no dice mucho. Estos afirman que se trataría de una solemnidad, sin decir de qué tipo (Lizama y Riquelme, 2021, p. 205; Irureta, 2016, p. 16; Lanata, 2018, p. 247), o no le atribuyen ningún carácter (Gamonal, 2020, p. 327; Humeres, 2005, p. 230; Macchiavello, 1989, p. 394), o simplemente no mencionan este requisito (Walker y Arellano, 2014, pp. 721-732). Por el contrario, parte de los estudiosos del CdT de 1931 sí se pronunciaron sobre la materia. Como se recordará, la norma de aquel entonces abordaba esta formalidad bajo la idea de remisión de un ejemplar del contrato colectivo al órgano laboral ${ }^{15}$, lo que indudablemente comprendía el registro de aquel instrumento. Según algunos, se estaba frente a una obligación patronal cuyo incumplimiento, a diferencia de la escrituración, no acarreaba la nulidad absoluta de dicho acto jurídico, pero sí la aplicación de una sanción administrativa (Pérez, 1937, p. 69); otros postulaban su carácter de solemnidad, sin especificarla, destinada a "garantizar oficialmente su conservación e integridad" (Escribar, 1944, p. 450), de modo que su infracción configuraba la nulidad del contrato, sin mencionar su naturaleza -absoluta o relativa- ${ }^{16}$. En esta misma línea, Gaete abogaba por la idea de solemnidad sin mayores distinciones, pero sin aclarar cuál era la sanción aplicable (1960, p. 258). Finalmente, autores como Humeres (1960, p. 45) y Walker (1941, p. 211) no se refirieron al punto.
Un análisis de esta formalidad permite identificarla como una exigencia de publicidad con fines esencialmente registrales (Corral, 2018, p. 617), ya que a través de ella se informaría y se oficializaría el contrato colectivo de trabajo a terceros que no participaron en su celebración, como sería el caso de la administración laboral y, eventualmente, los particulares que podrían interesarse en el contenido de este acto jurídico ${ }^{17}$; específicamente, se trata de una formalidad de simple noticia que persigue el registro público del acto jurídico (Corral, 2018, p. 618; Barcia, 2010, pp. 105-106; Vial, 2006, p. 219; Alessandri, Somarriva y Vodanovic; 2005, p. 313). Esto dotaría de una presunción de veracidad y de legalidad a las cláusulas de este contrato, mientras no sean impugnadas en sede judicial (Irureta, 2016, p. 17); atributo del que, obviamente, carecería el instrumento no registrado. Ni el art. 320 inc. $3^{\circ}$ ni otra disposición del CdT habilita a la administración laboral para revisar la legalidad y pertenencia de las cláusulas del contrato colectivo al momento de su registro, cuestión que refuerza el carácter de formalidad de simple noticia, sin perjuicio de sus atribuciones fiscalizadoras ex post y siempre dejando a salvo la competencia de los tribunales en estas materias ${ }^{18}$.

La libertad sindical también contribuye al planteamiento que aquí se sugiere; una de las dimensiones colectivas

\footnotetext{
${ }^{15}$ Véase nota 2.

${ }^{16}$ Es el significado que atribuimos al planteamiento de este autor que, al referirse a esta situación, señala: "La remisión del texto del convenio colectivo a la autoridad local del trabajo (...) le atribuimos también carácter de solemnidad que afecta a la eficacia del acto" (Escribar, 1944, p. 450).

${ }^{17}$ Con todo, si un particular solicita información a la administración laboral sobre un contrato colectivo de trabajo, su petición queda sujeta a la exigencia del artículo 20 de la ley N²0.285 "Sobre Acceso a la Información Pública", que señala: "Cuando la solicitud de acceso se refiera a documentos o antecedentes que contengan información que pueda afectar los derechos de terceros, la autoridad o jefatura o jefe superior del órgano o servicio de la Administración del Estado, requerido, dentro del plazo de dos días hábiles, contado desde la recepción de la solicitud que cumpla con los requisitos, deberá comunicar mediante carta certificada, a la o las personas a que se refiere o afecta la información correspondiente, la facultad que les asiste para oponerse a la entrega de los documentos solicitados, adjuntando copia del requerimiento respectivo.- Los terceros afectados podrán ejercer su derecho de oposición dentro del plazo de tres días hábiles contado desde la fecha de notificación. La oposición deberá presentarse por escrito y requerirá expresión de causa.- Deducida la oposición en tiempo y forma, el órgano requerido quedará impedido de proporcionar la documentación o antecedentes solicitados, salvo resolución en contrario del Consejo, dictada conforme al procedimiento que establece esta ley.- En caso de no deducirse la oposición, se entenderá que el tercero afectado accede a la publicidad de dicha información".

18 Véase, por ejemplo, el Ord. N 734, de 25/02/2019.
} 
de este derecho fundamental es la libertad de acción sindical, en virtud de la cual las organizaciones de trabajadores -en este caso un sindicato- son libres de determinar y encauzar sus más diversas actuaciones a los fines que autónomamente se proponen (Lizama y Riquelme, 2021, pp. 17-18; Sala Franco, 2020, pp. 5354; Gamonal, 2020, pp. 100-104; Lanata, 2018, p. 18; Thayer y Novoa, 2014, p. 145; Macchiavello, 1989, p. 124; Gaete, 1960, p. 215; Convenio OIT N 87, art. 3 $N^{\circ}$ 1), limitadas, evidentemente, a las prescripciones del ordenamiento jurídico. Ciertamente, la negociación colectiva, que suele concluir con la suscripción del contrato colectivo, es expresiva de dicha dimensión. Si la ley ya dispuso una solemnidad constitutiva -la escrituración-, sería del todo gravoso para esta libertad agregar otra exigencia de este tipo, máxime si las partes, a través de la suscripción de este instrumento, exteriorizan su plena y total aceptación con el contenido del mismo. Recuérdese que en el ámbito del derecho colectivo el sindicato se encuentra en un plano de igualdad negocial con el empresario (Macchiavello, 1989, pp. 47 y 61$62)^{19}$, desvaneciéndose así la desigualdad material que se observa en las relaciones individuales de trabajo. Varía, incluso, el alcance del principio protector, dirigido no a encauzar exclusivamente la dictación de normas estatales protectoras, sino a la creación de "instrumentos cuya eficacia deriva del número, de la disciplina, de la organización técnica y administrativa, del poder material de cada una de las partes" (Plá, 2015, p. 58).

Debido a todo lo anterior se afirma que la omisión de esta formalidad no impide que el contrato colectivo nazca a la vida del derecho y produzca sus efectos entre los suscribientes. Estos últimos, enfrentados a un conflicto - administrativo o judicial - referido a la existencia y autenticidad del instrumento, deberán aportar los elementos probatorios que permitan dilucidar esta controversia. Así las cosas, el incumplimiento de esta formalidad acarrearía la imposición de una multa administrativa (Pérez, 1937, p. 69) por infracción del art. 320 inc. 3 del CdT $^{20}$ y privaría al contrato colectivo de aquella presunción de legalidad y veracidad ya descrita. Respecto a la infracción y sin perjuicio de lo que podría suceder en la práctica, se piensa que esta debería recaer tanto en la empresa como en la organización sindical porque en ambos pesa la carga de registrar dicho acto jurídico. Conclusión que se apoya en el planteamiento de la jurisprudencia administrativa vigente, pues se estaría ante una controversia que tiene su origen en una infracción a la normativa laboral y no en una diferencia interna de la organización sindical ${ }^{21}$, caso este último donde prima, sin duda, la autonomía colectiva por sobre las competencias de fiscalización.

No se han encontrado pronunciamientos administrativos y judiciales que aborden expresamente esta formalidad de simple noticia. Los tribunales, al referirse a estos elementos que cubren al contrato colectivo de trabajo, únicamente mencionan la escrituración o las solemnidades en general22, constatación fáctica que abonaría una razón más para descartar su carácter de solemnidad constitutiva y, eventualmente, adherir a la propuesta ya sugerida.

Al igual que con la escrituración, las legislaciones española y francesa contemplan el registro del instrumento

\footnotetext{
19 Sobre el punto la jurisprudencia ha señalado que: "el derecho colectivo del trabajo es una expresión de la protección a los trabajadores, la cual ha sido reconocida desde antiguo, tanto por la doctrina como la jurisprudencia, como aquella parte más débil de la relación laboral, cuando actúa en singular, pero una vez que pasa a actuar en plural, entiéndase por tal, a los trabajadores unidos en un sindicato para negociar colectivamente, evidentemente pierde esta condición de parte «débil» y pasa a ser considerado como un igual o parte equivalente en un vínculo contractual”. Véase $1^{\circ} \mathrm{JLT}$ de Santiago, RIT S-14-2018, de 22/11/18 (considerando décimo quinto). En igual sentido, $2^{\circ}$ JLT de Santiago, RIT O-552-2017, de 26/05/2017 y CA de San Miguel, Rol № 362-2017 (Reforma Laboral), de 17/12/2017. ${ }^{20}$ El "Tipificador de hechos infraccionales y pauta para aplicar multas administrativas", en el capítulo 27 sobre "Negociación Colectiva" califica de grave "[n]o registrar en la Inspección del Trabajo el instrumento colectivo" (2021, p. 102).

${ }_{21}$ Ord. N ${ }^{\circ} 2374$, de 24/07/2002.

${ }^{22}$ Véase notas 7 a 9.
} 
colectivo de trabajo. A sabiendas de la distancia que separa a estos modelos normativos de negociación colectiva del nuestro, el ET regula dicha materia en el art. 90 números $2^{23}, 3^{24}$ y $5^{25}$. Adicionalmente, existe un $\mathrm{RD}$, el $713 / 2010$, de 28 de mayo, sobre registro y depósito de convenios y acuerdos colectivos de trabajo. De la sola lectura de la primera norma citada se advierte una nítida diferencia con su símil chilena: la facultad de la administración laboral de recurrir a la jurisdicción social - si estima que un instrumento colectivo contiene algún vicio de legalidad o lesiona gravemente intereses de terceros (90 $N^{\circ}$ 5). Por su parte, el artículo L2231-5-1 del Code du Travail habla de una base de datos nacional donde se ingresan los convenios y acuerdos colectivos de toda índole (de sucursales, grupos, interempresas y establecimientos) $^{26}$.

\section{Interpretación del contrato colectivo de trabajo}

2.1. Cinco cuestiones básicas sobre interpretación jurídica

Interpretar, en la acepción que aquí interesa, apunta a "explicar o declarar el sentido de algo"27; en otras palabras, es una acción ejecutada por una persona dirigida a atribuir significado a un ente (Tarello, 2013, p. 34; Squella, 2008, p. 377). Este concepto vulgar conecta con un tema de gran calado en la ciencia jurídica: la interpretación del derecho. No se pretende ahondar en este punto, pero sí se deben sentar un par de premisas -básicas, a estas alturas - generalmente aceptadas por los estudiosos de esta materia, a modo de encuadre del tema que nos ocupa, el de la hermenéutica del contrato colectivo de trabajo.

Primero, la interpretación del derecho es la operación practicada por un sujeto (intérprete) tendente a dotarlo de sentido (Tarello, 2013, p. 38; Squella, 2008, p. $377)^{28}$; aquella abarca las fuentes formales - ley en su sentido lato, costumbre y jurisprudencia-, los principios jurídicos -comunes y especiales de cada disciplina jurídica- y, en general, todo valor normativo (Tarello, 2013, pp. 40-42; Squella, 2008, p. 378; Ducci, 2006,

\footnotetext{
23 “Los convenios deberán ser presentados ante la autoridad laboral competente, a los solos efectos de registro, dentro del plazo de quince días a partir del momento en que las partes negociadoras lo firmen. Una vez registrado, el convenio será remitido al órgano público competente para su depósito".

24 "En el plazo máximo de veinte días desde la presentación del convenio en el registro se dispondrá por la autoridad laboral su publicación obligatoria y gratuita en el «Boletín Oficial del Estado» o en el correspondiente boletín oficial de la comunidad autónoma o de la provincia, en función del ámbito territorial del convenio".

25 "Si la autoridad laboral estimase que algún convenio conculca la legalidad vigente o lesiona gravemente el interés de terceros, se dirigirá de oficio a la jurisdicción social, la cual resolverá sobre las posibles deficiencias previa audiencia de las partes, conforme a lo establecido en la Ley 36/2011, de 10 de octubre, Reguladora de la Jurisdicción Social".

${ }^{26}$ La primera parte de la disposición citada indica que: "Les conventions et accords de branche, de groupe, interentreprises, d'entreprise et d'établissement sont rendus publics et versés dans une base de données nationale, dont le contenu est publié en ligne dans un standard ouvert aisément réutilisable. Ils sont publiés dans une version ne comportant pas les noms et prénoms des négociateurs et des signataires". La traducción libre sería "Los convenios y acuerdos de sucursales, grupos, interempresas, empresas y establecimientos se hacen públicos y se ingresan en una base de datos nacional, cuyo contenido se publica en línea en un estándar abierto que es fácilmente reutilizable. Se publican en una versión que no incluye los nombres y apellidos de los negociadores y firmantes".

${ }^{27}$ Real Academia Española, 2020. Recuperado de: https://dle.rae.es/interpretar [fecha de consulta: 5 de mayo de 2021].

${ }^{28}$ Según Tarello la idea de "interpretación del derecho" es más bien premoderna, inclinándose por la acepción moderna de "interpretación de la ley" (2013, pp. 37-38). Reconoce que ambas expresiones se utilizan indistintamente.
} 
pp. 37-39; Rodríguez, 1992, pp. 48-49). Bajo esta última noción quedarían comprendidas la ley emanada del poder legislativo, el decreto, la costumbre jurídica, el contrato, los dictámenes de los órganos administrativos, la sentencia judicial, los principios y demás.

Segundo, existe una relación contingente entre la interpretación y la aplicación del derecho. En efecto, todo sujeto, premunido de las cualidades necesarias, puede asignar significado a una norma jurídica, pero no necesariamente su actividad estará encaminada a aplicar inmediatamente aquel precepto $u$ otro valor normativo que interpreta, a volverlo operativo; así ocurre con las opiniones de la doctrina. Por su parte, quienes significan y aplican la norma - en un sentido activoson los órganos jurídicos legitimados para ello (Tarello, 2013, pp. 65-66; Squella, 2008, pp. 379-380 y 384; Ducci, 2006, p. 13), como sería el caso, en lo que aquí concierne, de la judicatura y la administración laboral. Su labor hermeneútica puede mirarse, regularmente, como un medio para concretar la norma a una situación determinada, creándose así un precepto específico derivado de aquella actividad (Squella, 2008, p. 381; Rodríguez, 1992, p. 50).

Tercero, la distinción entre textos y normas, donde los primeros contienen enunciados normativos, es decir, documentos con valor jurídico -leyes y demás-, mientras que las segundas son el resultado de la operación interpretativa, es decir, del significado dado por el intérprete a tales enunciados que, a su vez, forman parte del ordenamiento jurídico (Tarello, 2013, pp. 111114; Squella, 2008, p. 390). Distinción sutil que suele obviarse en la praxis jurídica, pues como bien advierte Squella:

en el modo de hablar habitual de los juristas, sean éstos profesores de derecho, abogados o jueces, está siempre presente la idea de la interpretación del derecho como una actividad referida a normas y no a los textos (...) pero a condición (...) de que se mantenga en claro la distinción entre las normas como significado de los enunciados que aparecen en los textos jurídicos y los textos jurídicos en que tales enunciados se contienen (2008, p. 391).

Cuarto, las variadas clases de interpretación. Sin tanto preámbulo, la hermenéutica del derecho se agrupa en distintos tipos; acá nos interesa recordar que aquella será judicial si proviene de un tribunal, actividad enmarcada en la resolución de un conflicto jurídico, donde dicho órgano interpreta-aplica las normas que zanjarán el asunto, y que cristaliza en una sentencia (Tarello, 2013, p. 73; Squella, 2008, p. 398; Ducci, 2006, p. 40); la interpretación será administrativa si es realizada por ciertos servicios públicos que están facultados para fiscalizar e interpretar la legislación; habitualmente se expresa en dictámenes donde, precisamente, se emplean las normas legales que operan en la esfera de atribuciones del respectivo órgano; y dotan de coherencia y uniformidad a la actividad de fiscalización de las normas interpretadas (Squella, 2008, p. 398; Ducci, 2006, pp. 42-43; Lizama, 1998, p. 36). Tal es el caso de la Dirección del Trabajo y sus dictámenes ${ }^{29}$. Finalmente, los propios sujetos de derecho pueden dotar de sentido a aquellos textos que contienen enunciados normativos (Squella, 2008, p. 399; Ducci, 2006, p. 41), como sucedería con la interpretación-aplicación de mutuo acuerdo del contrato colectivo de trabajo que realizan las partes sujetas al mismo. Con todo, carecen de facultades para resolver posibles diferencias no pacíficas en esta materia.

Quinto y final, del objeto interpretado. Desde el comienzo de este trabajo se ha recalcado el interés que se prestará a la interpretación dada por la administración laboral y los tribunales a un instrumento

\footnotetext{
${ }^{29}$ Por su parte, los ordinarios reiteran la doctrina contenida en los dictámenes. Ambos son rotulados indistintamente, con la primera denominación, para lo cual la administración laboral emplea la abreviatura "ORD.”. En este trabajo se trabajará con ambos documentos, en tanto dan cuenta de la actividad interpretativa de este órgano.
} 
colectivo específico: el contrato colectivo de trabajo. Afirmación reiterativa, pero solo en principio, por cuanto la determinación más o menos exacta de la naturaleza jurídica de esta convención, a la luz de la actual normativa que rige en este ámbito sirve para justificar, no sin reservas, la utilización de todo un cuerpo de reglas de interpretación, la de los contratos civiles, ubicadas entre los artículos 1560 a 1566 del CC.

2.2. Sobre la naturaleza jurídica del contrato colectivo de trabajo

Desde los orígenes de la disciplina se ha discurrido sobre la esencia del contrato colectivo, buscándose una explicación satisfactoria que dé cuenta de sus particularidades; diversas teorías, primero cercanas al derecho civil (contractualistas), después próximas al derecho público y al -en ese entonces - naciente derecho social (normativistas), han intentado, con mayor o menor éxito, ofrecer una respuesta ${ }^{30}$. Respecto de estas últimas, el planteamiento de Carnelutti nos sitúa inmediatamente en el punto a tratar. Para el afamado jurista italiano el contrato colectivo "tiene el cuerpo de contrato y el alma de la ley" (1927, p. 108) ${ }^{31}$, naturaleza jurídica bifronte que, a su vez, supone un componente obligacional y otro normativo.

Obligacional porque aquel acto jurídico es un acuerdo que contiene derechos y obligaciones recíprocos cuyos titulares son las partes contratantes -empresa, sindicato y trabajadores afiliados al mismo - (Gamonal, 2020, pp. 338-341; Lanata, 2018, pp. 246-247; Thayer y
Novoa, 2008, p. 149; Macchiavello, 1989, pp. 144-145 y 148); normativo debido a que predetermina, en términos generales y abstractos, el contenido fundamental de los contratos individuales de trabajo de los trabajadores que participan en el sindicato (Gamonal, 2020, pp. 338-341; Lanata, 2018, pp. 6, 238 y 255; Thayer y Novoa, 2008, p. 149; Macchiavello, 1989, pp. 147), proyectando sus cláusulas en aquellos contratos, tanto en los actuales como en los futuros. Con todo, en la práctica la distinción no es tan clara, al punto que se identifican cláusulas que "son a la vez normativas y obligatorias, de naturaleza híbrida, como por ejemplo aquellas que estatuyen límites al poder empresarial de administrar la relación laboral" (Gamonal, 2020, p. 340).

Novoa analiza la regulación del contrato colectivo en el CdT de 1931, ocasión en la que sugiere la recepción de los criterios publicistas y sociales, así como su naturaleza jurídica bifronte. A su juicio, el elemento obligacional fluía del art. $17^{32}$ porque el contrato colectivo instituye obligaciones a las partes que lo suscribieron (patrones y obreros del sindicato que concurrieron a su celebración), carácter que se refuerza por lo dispuesto en el art. 2133; el elemento normativo se desprendía del art. $18^{34}$ al irradiar, con carácter de ley, a los contratos individuales de trabajo de todos los miembros del sindicato, actuales y futuros, las cláusulas de este instrumento (Gamonal, 2020, p. 360; Novoa, 1996, pp. 55-56). Este elemento futuro dio pábulo para afirmar que el contrato colectivo "es la reglamentación contractual previa de las condiciones de trabajo, que no suprime, sino que integra, los contratos individuales con cláusulas ventajosas para el trabajador" (Walker, 1941, p. 211).

\footnotetext{
${ }^{30}$ Para este tópico y en nuestro medio, véase con provecho Gamonal, 2020, pp. 329-332; Lanata, 2018, pp. 241-247; Thayer y Novoa, 2008, pp. 145-149; y Pérez, 1937, pp. 35-56.

${ }^{31}$ La expresión original es "il corpo del contratto e l'anima della legge".

34 "El contrato colectivo obliga a todos los patrones que lo suscriban, por sí o por intermedio de sus representantes legales, y a todos los obreros que pertenecieren al Sindicato legalmente constituido que hubiere estado representado en la forma debida en la celebración de dicho contrato". El texto en Ruiz de Gamboa y Díaz, 1942, p. 36.

33 "Al Sindicato que hubiere subscrito un contrato colectivo de trabajo, corresponderá responsabilidad por las obligaciones contraídas por cada uno de los trabajadores que pertenezcan a él, y tiene, asimismo, personería suficiente para ejercer los derechos que a los mismos les corresponden". El texto en Ruiz de Gamboa y Díaz, 1942, p. 37.

35 "Las estipulaciones de un contrato colectivo se convierten en cláusulas obligatorias, o en parte integrante de los contratos individuales de trabajo que se celebren durante su vigencia”. El texto en Ruiz de Gamboa y Díaz, 1942, p. 36.
} 
Con la dictación del DL № 2.758, de 1979, el carácter normativo que manaba del art. 18 del CdT de 1931 "tuvo un vuelco estructural", según se reflexionará a continuación (Novoa, 1996, p. 56). Sin repetir el ejercicio histórico-legislativo efectuado para analizar las formalidades del contrato colectivo, por cuanto la revisión del cúmulo de normas involucradas excedería los límites de esta contribución ${ }^{35}$, conviene, eso sí, prestar atención a algunas modificaciones legislativas, sobre todo para entender la actual regulación en la materia que se comenta. Efectivamente, el artículo precitado fue sustituido por el art. 32 inc. $1^{\circ}$ del decreto en cuestión ${ }^{36}$, que limita las estipulaciones del contrato colectivo y de los fallos arbitrales únicamente a los trabajadores participes de una negociación respectiva. En la misma línea, la referida fuente legal modificó, entre otros, el art. 6 inc. $3^{\circ}$ del DL 2.20037, de 1978, que define dicho instrumento, circunscribiendo sus alcances exclusivamente a los trabajadores que lo celebraron. Igualmente, este mismo precepto consigna el efecto de reemplazo de cláusulas, aspecto de la esencia del elemento normativo, y que, con las salvedades del caso, solo afecta a los trabajadores que suscribieron el contrato colectivo. Cierra este grupo de normas del DL 2.758, de 1979, la posibilidad de derogación in peius del contrato colectivo ${ }^{38}$ y la prohibición de negociar con efecto erga omnes ${ }^{39}$, en un nivel superior y en relación a personas distintas a las inicialmente involucradas, incluso con acuerdo de estas (Novoa, 1996, p. 56).
Corolario de tales cambios legislativos fue el decaimiento del elemento normativo, en aras de una concepción marcadamente contractualista de este instrumento, por cuanto el efecto de estas normas quedó restringido a quienes participaban de una negociación, eliminándose así la proyección de las normas del contrato colectivo en otros contratos individuales distintos a los de quienes se les aplicaba este acto jurídico -los futuros-. A tal punto ello fue así, que algunos comentaristas de estas disposiciones no dudan en señalar que el contrato colectivo ahora podía explicarse a la luz de la teoría del mandato, porque la comisión negociadora del mismo actuaba como mera mandataria de los trabajadores del sindicato (mandantes) (Acuña, 1983, pp. 80-81; Novoa 1996, pp. 56-57). En consecuencia, "las normas que se crean no existen fuera de los contratos individuales a los que se incorporan por el hecho de estar involucrados dichos trabajadores en el contrato, sino dentro de esos contratos individuales (Novoa, 1996, p. 56).

El escenario actual, reformas legales mediante, no ha significado un pleno retorno del efecto normativo, sino una situación bastante sui generis. Se habla de "un contenido fundamentalmente normativo, pero de aplicación restringida" (Novoa, 1996, p. 58) o un "contrato normativo de alcance discreto" (Gamonal, 2020, p. 332). Aquí se adhiere a tales afirmaciones. Un breve recuento de ciertos preceptos servirá para comprender este predicamento.

\footnotetext{
36 "Las estipulaciones de los contratos colectivos y las de los fallos arbitrales sólo regirán respecto de los trabajadores que hayan sido parte de la negociación y tendrán una duración no inferior a dos años". El texto en Díaz, 1982, p. 165.

37 "El contrato es colectivo cuando se celebra entre un empleador y uno o más sindicatos de empresa, o entre un empleador y un grupo de trabajadores de la empresa unidos para tal efecto, o con unos y otros, con el objeto de establecer condiciones comunes de trabajo o de remuneraciones para los trabajadores que concurrieron a su celebración. Las estipulaciones de los contratos colectivos reemplazarán en su totalidad a las contenidas en los contratos individuales de los trabajadores que sean parte de aquéllos".

${ }^{38}$ Art. 9: "La negociación individual entre un empleador y un trabajador es un derecho irrenunciable. Ninguna disposición de esta ley podrá interpretarse en sentido contrario.- Por consiguiente, quedan prohibidas todas las acciones que directa o indirectamente atenten contra este derecho. Ningún sindicato o agrupación podrá ejercer presiones en tal sentido, ni solicitar o negociar condiciones para un trabajador que no pertenezca a ellos". El texto en Díaz, 1982, p. 156.

${ }^{39}$ Según Novoa (1996, p. 56), este aspecto fluye también del art. citado en la nota anterior, y del 12, en su número № 5 e inc. penúltimo que, respectivamente, prescriben: "No podrán ser objeto de negociación colectiva ni de ningún tipo de convenio o contrato colectivo, las siguientes materias: (...) N 5 Las que se refieran a remuneraciones y condiciones de trabajo de personas que no pertenezcan al sindicato o grupo negociador o de quienes no les es permitido negociar colectivamente" y "[l]as estipulaciones de un contrato colectivo o de una resolución arbitral que incidan en algunas de las materias referidas precedentemente, adolecerán de nulidad absoluta, aun tratándose de convenios colectivos suscritos directamente entre las partes, sin que haya mediado el procedimiento de negociación colectiva que regula esta ley". El texto en Díaz, 1982, pp. 156-157.
} 
Por una parte, la definición de instrumento colectivo del art. 320 inc. $1^{\circ}$ del CdT alude únicamente a los sujetos que participan en una negociación que conduce a la suscripción, en este caso, de un contrato colectivo. Novoa comenta una situación parecida, al revisar la modificación introducida por la ley $N^{\circ} 19.069$, de 1991, al concepto de contrato colectivo $^{40}$, en virtud de la cual se suprimió la frase "...para los trabajadores que concurrieron a su celebración"41 (1996, p. 57). Postula, asimismo, que el legislador no señala a quiénes se aplicaría la normativa del contrato; desde luego comprende a quienes negociaron, pero deja la puerta abierta para que, a diferencia de la normativa anterior, alcance a los futuros trabajadores (Novoa, 1996, p. 57). Sin embargo, no especifica bajo qué condiciones acontecería esto. Ahora bien, si se leen las disposiciones vigentes, ello puede suceder únicamente en dos casos. Primero, cuando los trabajadores ingresan a la empresa una vez celebrado el contrato colectivo y se afilian al sindicato que suscribió dicho instrumento. En esta situación no opera la aplicación automática, por el contrario, al tenor del art. 310 del $\mathrm{CdT}^{42}$, la administración laboral admite, bajo el prisma del principio de libertad sindical, que se pacte, en el mismo instrumento o en acuerdo posterior, la sujeción al contrato colectivo vigente de los nuevos socios del sindicato ${ }^{43}$. Segundo, la extensión de los beneficios contenidos en este instrumento en favor de los trabajadores sin afiliación sindical, regulada en el art. 322 incisos $2^{044}$ y $3^{045}$ del cuerpo legal precitado, siempre y cuando aquellos acepten este mecanismo y paguen todo o parte de la cuota ordinaria sindical. Algo similar podría suceder, al tenor del inc. final del art. recién nombrado, con la extensión a todos los trabajadores de las cláusulas de reajuste de remuneraciones conforme al Índice de Precios al Consumidor ${ }^{46}$.

Por otra parte, el efecto sustitutivo o imperativo del contrato colectivo de trabajo, que despliega toda su fuerza durante su vigencia. El art. 311 inc. $2^{\circ}$ del CdT señala que "Las estipulaciones de los instrumentos colectivos reemplazarán en lo pertinente a las contenidas en los contratos individuales de los trabajadores que sean parte de aquellos". Una vez más, Novoa, analizando el antiguo art. 348 inc. $1^{\circ}$ de este texto legal ${ }^{47}$, antecedente inmediato de la actual norma, afirma:

Con esta modificación los contratos individuales siempre mantienen su corporeidad jurídica; pudiendo sus estipulaciones ser reemplazadas en lo pertinente, por normas contenidas en otro instrumento, el colectivo, el cual mantiene plena individualidad jurídica y existen en sí, tiene vida propia, cuya normativa se

\footnotetext{
${ }^{40}$ Art. 120 inc. 2: "Contrato colectivo es el celebrado por uno o más empleadores con una o más organizaciones sindicales o con trabajadores que se unan para negociar colectivamente, o con unos y otros, con el objeto de establecer condiciones comunes de trabajo y de remuneraciones por un tiempo determinado".

${ }^{41}$ Art. 6 del DL N².200. Véase nota 37.

42 "Los trabajadores se regirán por el instrumento colectivo suscrito entre su empleador y la organización sindical a la que se encuentren afiliados mientras este se encuentre vigente, accediendo a los beneficios en él contemplados".

${ }^{43}$ Ord. N ${ }^{\circ} 2858 / 79$, de 27/06/2017.

44 "Las partes de un instrumento colectivo podrán acordar la aplicación general o parcial de sus estipulaciones a todos o parte de los trabajadores de la empresa o establecimiento de empresa sin afiliación sindical. En el caso antes señalado, para acceder a los beneficios dichos trabajadores deberán aceptar la extensión y obligarse a pagar todo o parte de la cuota ordinaria de la organización sindical, según lo establezca el acuerdo".

45 "El acuerdo de extensión de que trata el inciso anterior deberá fijar criterios objetivos, generales y no arbitrarios para extender los beneficios a trabajadores sin afiliación sindical".

46 "Sin perjuicio de lo anterior, el empleador podrá aplicar a todos los trabajadores de la empresa las cláusulas pactadas de reajuste de remuneraciones conforme a la variación del Índice de Precios al Consumidor determinado por el Instituto Nacional de Estadísticas o el que haga sus veces, siempre que dicho reajuste se haya contemplado en su respuesta al proyecto de contrato colectivo".

47 "Las estipulaciones de los contratos colectivos reemplazarán en lo pertinente a las contenidas en los contratos individuales de los trabajadores que sean parte de aquellos y a quienes se les apliquen sus normas de conformidad al artículo 122".
} 
proyecta sobre los contratos individuales (1996, p. 58).

La inderogabilidad in peius que se desprende del art. 311 inc. $1^{048}$ también es un elemento que contribuye a reforzar el elemento normativo (Gamonal, 2020, pp. 362364). Sin embargo, tanto el efecto imperativo como la inderogabilidad en perjuicio pierden fuerza cuando expira la vigencia de esta convención. No obstante, por el efecto ultra termine del contrato colectivo, recogido en el art. 325 del $\mathrm{CdT}^{49}$, subsisten discretamente ciertas cláusulas del mismo.

Se concluye, por las razones dadas, que el efecto normativo del contrato colectivo, que favorece su consideración de auténtica ley reguladora de las relaciones de trabajo en esta esfera (Escribar, 1944, p. 454; Macchiavello, 1989, p. 47; Montoya, 2007, $\mathrm{s} / \mathrm{p})$, existe en nuestro orden jurídico laboral, aunque menguadamente. Característica que, se piensa, incide en nuestra cultura jurídica, especialmente en la práctica, donde a este instrumento se le estima más como "ley del contrato" que como "ley formal". Afirmación que contrasta con la situación de otros países, por ejemplo, España; allí la naturaleza bifronte del contrato colectivo y los componentes que supone -obligacional y normativose reconocen más ampliamente que en nuestro país. En términos generales y simplemente a modo ilustrativo, se ha dicho que el convenio colectivo pese a que "se elabora con arreglo a mecanismos contractuales... proporciona por su ámbito de aplicación una regulación abstracta y general de vocación idéntica a la de la norma jurídica" (Martín, Rodríguez-Sañudo y García, 2016, pp. 365-366; también Montoya, 2019, p. 163; Cruz, 2015, p. 496); por ello el ET regula: i) su consideración como fuente de derecho y no meramente obligacional de la relación laboral50 (Martín, Rodríguez-Sañudo y García, 2016, p. 535); ii) la facultad de trabajadores y empresarios para regular las condiciones de trabajo, productividad $\mathrm{y}$, eventualmente, las de paz laboral (esta última, manifestación del contenido obligacional|51; iii) la eficacia general o erga omnes del convenio dentro de su ámbito de aplicación (empresa, sector o rama de actividad, interprofesional y de franja o grupo de trabajadores ${ }^{52}$; iv) la prohibición de negociación individual in peius ${ }^{53}$; y v) la indisponibilidad para el trabajador de los derechos reconocidos como indisponibles por convenio colectivo ${ }^{54}$.

A partir de las observaciones precedentes se extrae una consecuencia inmediata en esta materia: si el carácter de ley del contrato colectivo cede ante su carácter de contrato, ello podría explicar la utilización preferente de las reglas de hermenéutica de los contratos civiles antes que las de interpretación de la ley. Observación que se sustenta, asimismo, por la revisión emprendida de jurisprudencia administrativa y judicial en estos temas. Esto nos obliga a referirnos sucintamente a la aplicación supletoria del derecho civil al derecho del trabajo.

2.3. De la aplicación supletoria del derecho civil en el derecho del trabajo

\footnotetext{
48 "Las estipulaciones de un contrato individual de trabajo no podrán significar disminución de las remuneraciones, beneficios y derechos que correspondan al trabajador por aplicación del instrumento colectivo por el que esté regido".

49 "Extinguido el instrumento colectivo, sus cláusulas subsistirán como integrantes de los contratos individuales de los respectivos trabajadores afectos, salvo las que se refieren a la reajustabilidad pactada tanto de las remuneraciones como de los demás beneficios convenidos en dinero, los incrementos reales pactados, así como los derechos y obligaciones que sólo pueden ejercerse o cumplirse colectivamente y los pactos sobre condiciones especiales de trabajo".

${ }^{50}$ Art. 3 letra b) del ET.

${ }^{51}$ Art. 82.2: "Mediante los convenios colectivos, y en su ámbito correspondiente, los trabajadores y empresarios regulan las condiciones de trabajo y de productividad. Igualmente podrán regular la paz laboral a través de las obligaciones que se pacten".

${ }^{52}$ Art 82.3: "Los convenios colectivos regulados por esta ley obligan a todos los empresarios y trabajadores incluidos dentro de su ámbito de aplicación y durante todo el tiempo de su vigencia".

${ }^{53}$ Art. 3 letra c): "1. Los derechos y obligaciones concernientes a la relación laboral se regulan: c) Por la voluntad de las partes, manifestada en el contrato de trabajo, siendo su objeto lícito y sin que en ningún caso puedan establecerse en perjuicio del trabajador condiciones menos favorables o contrarias a las disposiciones legales y convenios colectivos antes expresados".

${ }^{54}$ Art. 3.5 del ET.
} 
La aplicación supletoria del derecho civil en materia laboral tiene adeptos en la disciplina. En efecto, Lanata participa de esta idea, condicionándola a la adaptación de aquel a los principios y normas del derecho laboral (2011, p. 59); reclama su uso en "todas aquellas materias no reguladas en la ley [laboral] y en que se hace indispensable recurrir a los conceptos del considerado derecho común" (2011, p. 43). Aquí también cabe ubicar las ideas de Mangarelli respecto del derecho laboral uruguayo (2014, pp. 13-14) y de Cruz en el marco de la contratación laboral española (2015, p. 91). Entre los civilistas chilenos, Tapia (2005, pp. 349-353) y Barrientos (2014, p. 40) postulan el amplio campo operativo supletorio del derecho civil y el CC en el derecho privado en general e, incluso, en el derecho público, pero con ciertas limitaciones. Así, el derecho del trabajo, como disciplina a medio camino entre el derecho privado y el derecho público, quedaría bajo su férula. Asimismo, la opinión de Corral, aunque su planteamiento podría inducir, aparentemente, a equívocos. Refiriéndose a la descodificación del derecho civil en Chile, primero esboza que "la legislación laboral constituyó finalmente un Código propio y no sólo se separó del Código Civil, sino del mismo derecho privado" (Corral, 2007, p. 10), para luego postular que "respecto del derecho laboral (...) las reglas del Código Civil no son residuales, sino supletorias" (2007, p. 11). En esta misma línea - descodificación y supletoriedad-se ubican las ideas de Guzmán Brito (1993, p. 55; 2007, pp. 155-158).

Desde el derecho administrativo, Vergara sugiere algo distinto. Acérrimo defensor de la autonomía disciplinar del derecho administrativo, circunscribe la aplicación del $\mathrm{CC}$ a los casos en que las leyes se remiten a este ( $\mathrm{v}$. gr. Código de Minería, Código de Aguas) y a las disciplinas cuyos principios no sean antitéticos con el derecho civil. También desmitifica la idea, infundada a su juicio, del CC como "derecho común" (2010, pp. 29-91). En este contexto, afirma que el CdT rechazó la supletoriedad del derecho civil. Basándose en el art. $1^{\circ}$ de este cuerpo legal, relativo a su campo de aplicación y al de sus leyes complementarias, sostiene que "la relación laboral (...) queda fuera del Código Civil” (2010, pp. 50-51).
En síntesis, puede decirse que, por regla general, la doctrina acepta la aplicación supletoria del derecho civil en el derecho del trabajo, tanto en su faz individual como colectiva, operación que debe considerar los especiales fundamentos, institutos y principios de este último.

2.4. De la interpretación del contrato colectivo de trabajo propiamente tal

Una primera aproximación a la hermenéutica del contrato colectivo obliga a tomar partido por las materias que se desarrollarán en este punto, en desmedro de otras; se cree que un abordaje del tema desde la casuística administrativa y judicial sirve para dar cuenta, brevemente, de al menos dos puntos: i) la utilización de las normas de interpretación de los contratos ubicadas en el CC y ii) el significado dado por los intérpretes, es decir, la Dirección del Trabajo y los tribunales de justicia, a algunas de estas disposiciones.

Internarse en este tema a través de la jurisprudencia confirma el interés que se predica por la interpretación operativa del derecho, en tanto los órganos que la practican resuelven las disidencias que las partes fueron incapaces de zanjar previamente, contribuyendo así al restablecimiento de la paz social; a su vez, este conflicto "puede consistir pura y simplemente, en la discrepancia sobre la interpretación que haya de darse a una norma del convenio, o en tal discrepancia interpretativa con ocasión de una concreta demanda [judicial]" (Montoya, 1997, p. 128).

Desde ya conviene advertir al lector la estrecha vinculación que aquí se postula entre la forma escrita de este contrato y la interpretación del mismo, a partir de lo planteado por Baraona. Este, al insistir en el giro objetivo del art. 1560 del CC, asunto que se aclarará oportunamente, postula que la búsqueda del significado del contenido de los actos y contratos solemnes debe buscarse en el mismo texto, por cuanto la ley ha exigido canalizar el consentimiento contractual de las partes de ese modo, "lo que ciertamente impone una restricción 
al intérprete (...) para excluir indagaciones externas al contrato mismo, de cara a fijar o determinar el material que debe interpretarse" (2016, p. 443). Razonamiento que se suscribe, aunque con ciertos matices, según se revisará. De todas formas, aquel pensamiento autorizaría la exclusión de las cláusulas tácitas en el contrato colectivo de trabajo, punto refrendado por la jurisprudencia judicial ${ }^{55}$ y administrativa ${ }^{56}$, así como por la doctrina laboral; para esta última, la solemnidad del contrato y la inexistencia de reglas semejantes a las de los artículos 8 y 9 del CdT, sobre presunción de laboralidad y consensualidad del contrato individual de trabajo, respectivamente, impiden dar cabida a estas estipulaciones voluntarias que suplementen o muten los instrumentos colectivos con alcance general a todos los sujetos involucrados (Fernández, 2013, p. 103).

En nuestro medio, la interpretación jurídica en el derecho colectivo y, asimismo, del contrato colectivo, ha recibido una escasa atención por parte de la doctrina laboral. Al respecto, Macchiavello distingue entre las leyes sobre derecho colectivo y los contratos colectivos; según él las primeras son prioritariamente públicas y de orden público, afirmación rotunda que lo lleva a descartar, en temas de hermenéutica, las normas que sobre este tema figuran en el CC (artículos 19 a 24), porque aquellas se aplican solamente a las leyes de derecho privado (1989, p. 45), de modo que los preceptos de esta parcela jurídica han de interpretarse teleológicamente "sobre todo en caso de vacíos, contraindicaciones, oscuridades, o cuando la lectura de éstas se contrapone con el ámbito y los fines propios de la protección laboral" (1989, p. 45). Coincidentemente, Gamonal postula lo mismo y agrega otro criterio rector en este tópico, el principio de libertad sindical, el cual sirve para determinar el sentido y alcance de los reglas legales y constitucionales, "en forma extensiva respecto de sus titulares y restrictiva de los poderes públicos" (2020, p. 105).
Macchiavello afirma que los contratos colectivos admiten también una interpretación teleológica. Si bien señala que, a diferencia del derecho individual, los sujetos colectivos (organizaciones sindicales y organizaciones gremiales) se encuentran en un plano de igualdad y, por lo mismo, la aplicación de las normas de derecho común sería congruente con esta premisa, opta por limitar este pensamiento únicamente a la parte obligacional de la convención, específicamente a las cláusulas que regulan derechos y obligaciones inmediatas para tales sujetos colectivos. La parte normativa del contrato, que afecta a todos los trabajadores, al asemejarse más a una ley formal que a una de tipo contractual, debe significarse conforme con el criterio teleológico (1989, pp. 46-47). Apelando a la naturaleza jurídica bifronte del contrato colectivo (contrato-ley), Gamonal postula que se emplearán las normas de interpretación del contrato o de la ley, según sea la tesis que adopte el intérprete, operación que "deberá reconocer las particularidades de esta figura, lo que debe acercarlo a las normas sobre interpretación de la ley" (2020, p. 106). Novoa, en su momento, ya había observado la desatención de la doctrina a esta discusión, la que tampoco era trascendente en nuestro medio. Entre las normas de hermenéutica de la ley y las homónimas relativas a los contratos, opta por las primeras, pero reconoce la utilidad de ambos grupos de reglas (1996, p. 61).

Se piensa que la jurisprudencia administrativa y judicial no ha reflexionado mayormente sobre el tema, aspecto que se refrenda al examinar sus pronunciamientos, donde se aprecia una aplicación preferente de los preceptos contractuales. Esto, en todo caso, es coherente con la visión más negocial que pesa sobre dicho acto jurídico y su limitado efecto normativo. Si fuese necesario inclinar la balanza por uno u otro cuerpo de normas, conviene evocar la realista observación de D’Ors: "el derecho [es] aquello que aprueban los jueces” (1989, p. 24).

\footnotetext{
55 Véase nota 7.

56 Véanse, entre otros: Ord. No 7120/331, de 07/12/1992, Ord. 3496/267, de 30/07/1998, Ord. 3988/156, de 31/08/2004 y Ord. 5318/206, de 21/12/2004.
} 
Una primera constatación jurisprudencial se vincula con el reconocimiento expreso de las normas de interpretación de los contratos del CC para determinar el significado de sus cláusulas. En este punto es interesante el planteamiento judicial que relaciona la idea de igualdad negocial (empleador-sindicato) con las reglas de hermenéutica recién citadas, al punto que aquella equiparación se erige como exigencia para aplicar toda la normativa civil en esta materia (efectos de las obligaciones y contratos), y especialmente las disposiciones ubicadas entre los artículos 1560 a 1566 del CC; juicio que desplaza, incluso, a ciertos principios laborales como la primacía de la realidad y la regla in dubio pro operario que deriva del principio protector ${ }^{57}$. Otros razonamientos validan la aplicación supletoria de estos preceptos civiles $^{58}$, a lo que se agrega, en ciertos casos, su adecuación con los principios de la disciplina, "entre otros, la irrenunciabilidad de los derechos laborales conforme el artículo $5^{\circ}$ del Código del Trabajo, los principios de protección y tutela efectiva, los que sin duda forman parte del prisma con el cual se debe mirar la regulación interpretativa antes aludida y que rige de modo subsidiario en este ámbito"59. Por su parte, ciertas sentencias, en el marco de la aplicación de una norma de interpretación contractual específica, refrendan el uso de aquella en materia laboral60.
La doctrina ha enfatizado que la Dirección del Trabajo, en ejercicio de su función interpretativa de la legislación laboral, también recurre a las reglas civiles para dotar de significado a los instrumentos colectivos, categoría que incluye el contrato colectivo (Gamonal, 2020, p. 107). En varios de sus pronunciamientos postula expresamente el uso de esta normativa para determinar "el sentido y alcance de tal estipulación"ø1.

Se cree que la remisión y utilización de la tantas veces citada normativa civil debe conectarse, inexorablemente, con el conjunto de reglas y principios que caracterizan al derecho del trabajo, especialmente la libertad sindical, garantía fundamental elevada, a su vez, a la categoría de principio jurídico de la disciplina, pues articula y explica buena parte de las instituciones del derecho colectivo del trabajo. Con todo, no se ha encontrado una mención y desarrollo robusto de este elemento en las sentencias revisadas.

Si bien se reconoce la necesidad de ahondar en el punto recién abordado, preliminarmente no se advierte una contradicción dogmática insalvable entre los institutos, normas y principios laborales con los preceptos civiles. Es más, la igualdad de las partes (empleador-sindicato) en la esfera de la contratación colectiva es un elemento

\footnotetext{
$572^{\circ}$ JLT de Santiago, RIT O-552-2017, de 26/05/2017: "la norma contenida en un contrato colectivo de trabajo, se acuerda, negocia y pacta entre el empleador y un grupo de trabajadores que se encuentran ligados entre sí bajo un Sindicato, quien representa los intereses de carácter laboral y colectivo de quienes son sus afiliados, de manera tal, que existe un equilibrio de las fuerzas negociadoras. Lo anterior, conlleva necesariamente a fijar como parámetro de interpretación de la forma de pago de las cláusulas contenidas en los contratos colectivos convenidos, en razón de las disposiciones del derecho común contenidas entre los artículos 1560 a 1566 del Código Civil, relativos a la hermenéutica contractual y no en el análisis propio de los principios del derecho del trabajo, tales como, primacía de la realidad o in dubio pro operario" (considerando décimo cuarto).

${ }^{58}$ CA de Rancagua, Rol N²04-2016, de 24/01/2017: "que el Código del Trabajo, no contiene normas sobre interpretación de los contratos, es que debe recurrirse a las reglas que contempla nuestra recopilación sustantiva civil, en razón del carácter general, común y supletorio de sus normas, respecto de todas las demás ramas que conforman el ordenamiento jurídico" (considerando noveno). También CA de San Miguel, Rol № 362-2017 (Reforma Laboral), de 17/12/2017 (considerando séptimo).

59 JLT de Copiapó, RIT O-285-2018, de 29/03/2019 (considerando noveno).

${ }^{60}$ CA de Santiago, Rol No 334-2014, de 04/12/2014 (Reforma Laboral): "conforme a lo dispuesto en el artículo 1560 del Código Civil, se dispone que, conocida claramente la intención de los contratantes debe estarse más a ésta que a lo literal de las palabras, norma del derecho común que se hace aplicable en la especie, por no contradecir principio alguno del derecho laboral, y que deja de manifiesto que la interpretación de los contratos es una cuestión de hecho" (considerando quinto).

61 Ord. N N 3558/193, de 17/06/1997. También Ord. № 4224/172, de 24/07/1996; Ord. № 5109/345, de 01/12/2000; Ord. № 2661, de 11/06/2018; Ord. N² 2781, de 21/06/2018; Ord. N 4355, de 10/09/2019; y Ord. N 676, de 05/02/2020.
} 
que fomenta el uso de tales normas civiles.

A propósito de esta corroboración jurisprudencial, la doctrina y los tribunales de España, desde su propia realidad normativa, han analizado el punto; para estos el convenio colectivo tiene un carácter ambivalente, es decir, un contrato por su forma de producirse y su contenido obligacional, y también un tipo de ley por la eficacia jurídica (normativa) que produce ${ }^{62}$. De ahí la opinión de los autores en torno al uso alternativo de, por una parte, las normas de interpretación de la ley, y por otra, las homónimas del contrato, juicio que, además, sustentan con la jurisprudencia judicial correspondiente (Montoya, 2019, p. 190; Martín, Rodríguez-Sañudo y García, 2016, pp. 366-367; Moreno, 2016, s/p; Cruz, 2015, pp. 530-531; Casas y Olea, 2000, pp. 15951597; Montoya, 1997, pp. 135-136; Gil, 1992, pp. 242244; Iglesias, 1988, pp. 76-78); jurisprudencia que ha planteado lo siguiente: "el carácter mixto del ConvenioColectivo - norma de origen convencional/contrato con eficacia normativa - determina que su interpretación ha de atender tanto a las reglas legales atinentes a la hermenéutica de las normas jurídicas como a aquellas otras que disciplinan la interpretación de los contratos"63. Por lo mismo, tampoco es extraño la invocación de una $u$ otras reglas de hermenéutica ${ }^{64}$.

Una segunda comprobación jurisprudencial guarda relación con el significado dado tanto por la jurisprudencia judicial como por la administrativa a los preceptos de interpretación contractual. Aspecto llamativo porque, a partir del mismo, se puede concluir no solo una remisión formal a tales pautas, sino también una correspondencia material con aquellas; veamos algunas situaciones.
El art. 1560 del $\mathrm{CC}^{65}$ es la regla de hermenéutica más relevante $\mathrm{y}$, para algunos, se erige como principio rector de las restantes (López, 2010, p. 388); bajo un contexto de creciente objetivación del contrato, de apartamiento de las doctrinas subjetivas, se tiende a dar más importancia a la letra de este acto jurídico por sobre la intención de los contratantes (Baraona, 2016, p. 439; Alcalde, 2006, p. 552), en franca oposición a lo planteado por la arraigada corriente tradicional que privilegia el elemento subjetivo (Elorriaga, 2018, pp. 413-414; Figueroa, 2012, p. 161; López, 2010, p. 388; Abeliuk, 2008, p. 118; Barcia, 2007, p. 23; Ducci, 2006, pp. 204 y 207-209; Rodríguez, 1990, p. 155). Para Baraona, el art. 1560 contiene dos reglas interpretativas; la primera, de carácter implícita, dictamina una interpretación literal de los términos usados, mientras que la segunda, de carácter explícita, supone indagar en la voluntad de los contratantes, siempre que sea "conocida claramente". Esto acaecerá "cuando la literalidad contractual no es fácil de comprender, por vaguedad, ambigüedad, oscuridad, imprecisión, falta de coherencia o contradicción con otras cláusulas estipulaciones o con el contrato en su conjunto o por otra razón, o queda sobrepasada por otra manifestación del "acuerdo negocial" (2016, p. 441; igualmente Alcalde, 2006, pp. 552-553). Sin embargo, el mismo autor, según se vio, propone una limitación en el caso de los actos y contratos solemnes, la que impediría ir más allá del texto del contrato (2016, p. 443).

La judicatura laboral, en ejercicio de sus competencias, ha recurrido a esta norma, dotándola del sentido recién descrito, optando por uno u otro criterio; en efecto, cuando identifica los preceptos atingentes al conflicto, ha afirmado "que la regla fundamental es la del artículo 1560 de dicho

62 Véase la última parte del punto 3.2.

63 STS 5583/2015, Sala de lo Social, № de recurso 365/2014, de 02/12/2015 (fundamentos de derecho 3.4). También STS 717/2019, Sala de lo Social, № de recurso 78/2018, de 22/10/2019 (fundamentos de derecho 2). STS 713/2019, Sala de los Social, Nº de recurso 195/2018, de 15/10/2019 (fundamentos de derecho 2).

${ }_{64}$ Al respecto y de modo ejemplar, STS 5597/2015, Sala de los Social, No de recurso 68/2015, de 02/12/2015 (fundamentos de derecho 3). STS 7211/1994, Sala de los Social, No de recurso 1096/1994, de 08/11/1994 (fundamentos de derecho 6).

65 "Conocida claramente la intención de los contratantes, debe estar más a ella que a lo literal de las palabras". 
cuerpo normativo, que establece la primacía de la intención de las partes en caso de conflicto. Así, puede ocurrir por una parte que su redacción sea ambigua en cuyo caso deberá investigarse la intención de las partes o bien que la redacción sea clara sin doble interpretación posible, ni contradicción, en cuyo caso no podrá desconocerse su letra"66. En este razonamiento la adhesión al parámetro subjetivo es nítida ${ }^{67}$. Nitidez que desaparece en otros pronunciamientos, pero que igualmente devela una preferencia por una de estas alternativas; así, por ejemplo, cuando se invoca la regla ya citada y se postula que a partir de la sola lectura de una cláusula se desprende la intención de las partes, optándose, se cree, por el parámetro objetivo ${ }^{68}$. Declaración que no supone, necesariamente, una lectura auténticamente literal de la estipulación contractual, pues aquí la amplia discrecionalidad del juez en su labor de significación puede conducir a resultados hermenéuticos contradictorios ${ }^{69}$. Finalmente, otros fallos adhieren a la tesis objetiva, pero buscando la intención claramente manifestada de los contratantes en otros instrumentos distintos a la convención colectiva ${ }^{70}$, o derechamente en las actuaciones desplegadas en el proceso de negociación colectiva ${ }^{71}$.

Hasta aquí se ha postulado la limitación a la que se ve expuesto el intérprete al indagar el significado de un acto solemne, como sería el caso del contrato colectivo de trabajo. En principio, su actividad debe girar en torno al instrumento donde figuran las cláusulas, premisa que admite cierta precisión. Sin entrar en detalles, aquel sí podría acudir a otros documentos para dilucidar el sentido de una estipulación contractual, sobre todo si están suscritos por ambas partes (empleador-sindicato) y abordan la materia objeto de la controversia; por ejemplo, un acta de mediación otorgada ante una mediadora laboral de la Dirección del Trabajo ${ }^{72}$. Esto no con el propósito de introducir nuevas cláusulas al contrato, tampoco para modificar radicalmente su contenido, sino únicamente para clarificarlo. No obstante, siempre queda a salvo la modificación expresa del contrato colectivo, a través de un acto posterior a su celebración, por mutuo acuerdo de las partes, el que debe constar por escrito, es decir, ser solemne.

Para cerrar el punto, la jurisprudencia administrativa pareciera plegarse al estándar subjetivo, porque en su opinión: "al interpretarse un contrato debe buscarse ante todo cual ha sido la intención de las partes que intervinieron en su celebración, puesto que tales instrumentos se generan mediante su voluntad y, por tanto, para fijar su sentido y alcance de[be] atenderse, más que a lo que en ellos expresan, a lo que realmente han querido estipular"73.

Los tribunales, asimismo, han invocado la regla del art. 1561 del $\mathrm{CC}^{74}$ tocante a la generalidad de los términos del

\footnotetext{
$662^{\circ}$ JLT de Santiago, RIT O-4200-2019, de 12/03/2020 (considerando undécimo).

67 También CA de Rancagua, Rol № 204-2016, de 24/01/2017 (Reforma Laboral) (considerando décimo), Juzgado de Letras, Garantía y Familia de Peumo, RIT O-11-2019, de 12/08/2019 (considerando octavo), CA de Santiago, Rol № 334-2014, de 04/12/2014 (considerando quinto) (Reforma Laboral), JLT de Copiapó, RIT O-285.2018, de 29/03/2019 (considerando noveno).

${ }^{68}$ JLT de lquique, RIT O-548-2016, de 30/12/2016 (considerando décimo), CA de Rancagua, Rol N 268-2019, de 23/12/2019 (Reforma Laboral) (considerando sexto) y CA de San Miguel, Rol N 362-2017, de 07/12/2017 (considerando noveno).

${ }^{69} \mathrm{CA}$ de lquique, Rol No 7-2017, de 16/03/2017 (Reforma Laboral). Este tribunal, conociendo de la causa indicada en la nota precedente, llegó a una conclusión diversa: "Pues bien, en este caso, la sentenciadora en su labor interpretativa, se alejó no sólo del tenor literal de la cláusula transcrita, sino que, con el fin de darle un sentido a su juicio más coherente, desnaturalizó el contenido de la convención, transgrediendo de esa manera la ley del contrato y expreso tenor del artículo 1560 del Código Civil” (considerando octavo).

${ }^{70}$ CA de Valparaíso, Rol N 50-2014, de 17/10/2014 (considerandos séptimo y octavo) (Cobranza).

'2 ${ }^{\circ}$ JLT de Santiago, RIT O-552-2017, de 26/05/2017, (considerando décimo quinto).

Véase nota 70 (considerandos octavo a décimo cuarto).

72 Ord. N 676, de 05/02/2020. Asimismo, Ord. 4224/172, de 24/07/1996; Ord. 3558/193, de 17/06/1997; Ord. N²661, de 11/06/2018;

${ }_{73}$ Ord. No 2781, de 21/06/2018; Ord. N 6456, de 20/12/2018; y Ord. N 4355, de 10/09/2019.

74 "Por generales que sean los términos de un contrato, sólo se aplicarán a la materia sobre que se ha contratado".
} 
contrato; estos, aunque su significado vaya más allá de lo querido por las partes, hay que constreñirlos únicamente al propósito de aquellas, para evitar cualquiera aplicación a situaciones parecidas, pero que no fueron consideradas por quienes suscribieron el acto jurídico (Elorriaga, 2018, p.419; Figueroa, 2012, p. 162; López, 2010, pp. 397398; Abeliuk, 2008, p. 119; Barcia, 2007, p. 28; Ducci, 2006, pp. 215-216; Rodríguez, 1990 p. 155), es decir, "por amplia que pueda ser la estipulación, siempre se entiende restringida exclusivamente a lo mencionado en el contrato" (Elorriaga, 2018, p. 419). Sin embargo, esta limitación debe conciliarse con lo dispuesto en el art. 1546 del $\mathrm{CC}^{75}$, especialmente las exigencias derivadas de la buena fe contractual, principio que hará primar, en caso de ambigüedad del tenor literal, la intención claramente conocida de las partes, y del cual también emanan los deberes colaterales de conducta (Elorriaga, 2018, p. 420).

En su momento, la Corte Suprema, aplicando esta normativa, concluyó que la expresión "regalías" utilizada en una cláusula de un contrato colectivo, se extendía únicamente a las materias objeto de dicha convención, descartando así la procedencia y pago de otros beneficios, también de la misma denominación, pero que no aparecían expresamente en el instrumento colectivo ${ }^{76}$.
El fallo que se comenta, adicionalmente, recurrió al precepto del art. 1564 inc. 2 del CC, en virtud del cual las cláusulas de un contrato "Podrán interpretarse por las de otro contrato entre las mismas partes y sobre la misma materia". Se justificó su uso para ejemplificar que la palabra "regalías" se aplicó de la forma precedentemente explicada ${ }^{77}$, incluso, a los contratos colectivos anteriores celebrados entre la empresa y el sindicato.

La doctrina explica que la disposición en cuestión facultaría al juez para indagar la intención de las partes en un contrato distinto, anterior o posterior, al que se interpreta (Elorriaga, 2018, pp. 428-429; López, 2010, pp. 399; Ducci, 2006, pp. 216-217; Rodríguez, 1990 p. 156). Esto será posible en la medida que el contrato objeto de la interpretación regule la misma materia, pues de lo contrario se corre el riesgo de incorporar una cláusula inexistente. La razón práctica de esta disposición la ilustra Ducci:

Existen muchos contratos recurrentes entre unas mismas partes (...) Al renovarlos (...) por el desarrollo práctico que han tenido los anteriores, mantendrán sus términos e incluso los harán más breves. En cambio, si quieren innovar sobre esta práctica tendrán buen cuidado de expresarlo (2006, p. 217).

\section{Conclusiones}

Como resultado de esta investigación, se pueden extraer las conclusiones que a continuación se indican:

Se ha comprobado, a través de un sencillo ejercicio histórico-normativo, que la escrituración y registro del contrato colectivo de trabajo son dos exigencias que se retrotraen al CdT de 1931; actualmente, modificaciones legales mediante, estas formalidades

\footnotetext{
75 "Los contratos deben ejecutarse de buena fe, y por consiguiente obligan no sólo a lo que en ellos se expresa, sino a todas las cosas que emanan precisamente de la naturaleza de la obligación, o que por la ley o la costumbre pertenecen a ella".

${ }^{76}$ CS, Rol No 2209-2002, de 14/11/2002 (considerandos séptimo y octavo).

77 Véase nota 76 (considerando sexto).
} 
figuran en el art. 320 inc. 3 del citado cuerpo legal. Premunidos de la doctrina laboral actual, de aquella surgida al alero del CdT de 1931 y de la civilística, se ha advertido que ambos requisitos constituyen auténticas formalidades, aunque difieren en cuanto a su tipo.

De una parte, la escrituración es una solemnidad - especie de formalidad- constitutiva, cuyo incumplimiento acarrea la nulidad absoluta de esta convención, por tratarse de un elemento inherente a esta especie de contrato. También, su importancia apunta a evitar ulteriores disputas sobre su contenido, a garantizar y facilitar su conocimiento, y a dotarlo de certeza jurídica al tornar indudable su existencia. De otro lado, el registro es una formalidad de simple noticia que busca inventariar el acto jurídico ante la administración laboral. Esto dotaría de una presunción de veracidad y de legalidad a las cláusulas de este contrato, mientras no sean impugnadas judicialmente, atributo del que adolecería el instrumento colectivo que omite este requisito. Ciertamente, esta omisión no impide que produzca plena eficacia jurídica entre las partes, aunque ello traería aparejado la imposición de una multa administrativa por infracción a la legislación laboral, tanto, según se ha visto, a la empresa como a la organización sindical. No obstante, esta última proposición pareciera diferir con lo que ocurre en la práctica.

Lajurisprudencia administrativa y judicial se han referido casi exclusivamente a la escrituración, planteamiento que abona una razón adicional para descartar el carácter de solemnidad constitutiva del registro. Por su parte, la materia hasta aquí reseñada ha recibido un tratamiento mucho más detallado en la legislación y doctrina extranjeras estudiadas (España y Francia).

Respecto a la interpretación de esta convención, se han tratado diversos aspectos que se estiman fundamentales para desarrollar una aproximación a la hermenéutica de este instrumento. Así, las premisas básicas en este ámbito confirman que el tantas veces citado contrato es un valor normativo cuyo intérprete lo dota de significado; que quienes significan y aplican la norma - en un sentido activo - son los órganos jurídicos legitimados para ello, en este caso, la judicatura y la administración laboral; que la distinción entre textos y normas, aunque inexistente en la práctica, supone que los primeros contienen enunciados normativos, es decir, documentos con valor jurídico, mientras que las segundas son el resultado de la operación interpretativa; que las clases de hermenéutica revisadas en este estudio son la judicial y la administrativa; y que el objeto interpretado es, evidentemente, el contrato colectivo de trabajo.

En cuanto a la naturaleza jurídica del instrumento colectivo analizado, se ha postulado, a partir de la doctrina vigente en la materia, su condición bifronte (contratoley) y la coexistencia de un componente obligacional y otro normativo; estos últimos han experimentado una serie de transformaciones de interés en la legislación laboral chilena, las que fueron debidamente identificadas y reseñadas a la luz de la escasa doctrina nacional que se ha fijado en ellas. Como resultado de estas observaciones se ha expresado que el denominado efecto normativo, el cual favorece su consideración de auténtica ley reguladora de las relaciones de trabajo en el plano colectivo, existe en nuestro orden jurídico laboral, pero menguadamente. Atributo que, se piensa, impacta en nuestra cultura jurídica, especialmente en la práctica, donde, según se ha corroborado, a este instrumento se le estima más como "ley del contrato" que como "ley formal", lo que contrasta con la situación española, donde, por las razones ya esgrimidas en el cuerpo del trabajo, la naturaleza bifronte del contrato colectivo y los componentes que supone - obligacional y normativose reconocen más ampliamente que en nuestro país.

Finalmente, a partir del examen de una serie de pronunciamientos administrativos y judiciales se ha constatado, en primer lugar, la utilización y el reconocimiento, mayoritariamente expreso, de las reglas de interpretación de los contratos del CC para dotar de 
significado a las estipulaciones del contrato colectivo de trabajo, confirmándose así el carácter supletorio del derecho civil en el derecho del trabajo. Sin perjuicio de las tendencias reconocidas, se cree que la remisión y utilización de la normativa civil debe conectarse, inexorablemente, con el conjunto de reglas y principios que caracterizan al derecho del trabajo, especialmente la libertad sindical, derecho fundamental elevado, a su vez, a la categoría de principio jurídico de la disciplina, el cual articula y explica parte importante de las instituciones del derecho colectivo del trabajo. Una segunda corroboración jurisprudencial ha permitido afirmar que tanto los tribunales como la administración laboral, dotan de sentido a los preceptos de interpretación contractual alineándose con las opiniones sostenidas por la dogmática civil. Al menos, así lo demuestra el examen de los pronunciamientos que recurren a los artículos 1560, 1561 y 1564 inc. 2 del CC. Por su parte, se ha delineado la necesidad de considerar el carácter solemne del contrato para enmarcar la actividad del intérprete, el que podrá acudir a otros documentos para dilucidar el sentido de una cláusula contractual, sobre todo si están suscritos por ambas partes (empleador - sindicato) y abordan la materia objeto de la controversia, siempre y cuando estos no alteren radicalmente su contenido.
Abreviaturas
Art.: Artículo
CA: Corte de Apelaciones
CC: Código Civil
CdT: Código del Trabajo
DFL: Decreto con Fuerza de Ley
DL: Decreto Ley
ET: Estatuto de los Trabajadores (España)
Inc.: Inciso
JLT: Juzgado de Letras del Trabajo
OIT: Organización Internacional del Trabajo
Ord.: Ordinario
RD: Real Decreto (España)
RUJ: Recurso de Unificación de Jurisprudencia
s/p: sin número de página
STS: Sentencia Tribunal Supremo (España)
V.gr.: Verbigracia

\section{Referencias bibliográficas}

Abeliuk, R. (2008). Las obligaciones (5 ed.). Tomo I. Santiago de Chile: Editorial Jurídica de Chile.

Acuña, F. (1983). La negociación colectiva y el contrato colectivo de trabajo. Naturaleza jurídica y características.

Santiago de Chile: Memoria para optar al grado de licenciado en la Facultad de Derecho de la Universidad de Chile (inédita).

Alcalde, J. (2007). Una nueva lectura de las normas de interpretación de los contratos. En Corral, H. \& Rodríguez, M.

S. (coords). Estudios de Derecho Civil II (pp. 549-570). Santiago de Chile: AbeledoPerrot/LegalPublishing.

Alessandri, A.; Somarriva. M. \& Vodanovic A. (2005). Tratado de derecho civil. Partes preliminar y general (7 $7^{\mathrm{a}} \mathrm{ed}$.).

Tomo I. Santiago de Chile: Editorial Jurídica de Chile.

Barcia, R. (2007). Lecciones de derecho civil chileno. De las fuentes de las obligaciones. Tomo II. Santiago de Chile:

Editorial Jurídica de Chile.

Barcia, R. (2010). Lecciones de derecho civil chileno. Del acto jurídico. Santiago de Chile: Editorial Jurídica de Chile. Barona, J. (2016). La interpretación contractual: una insistencia en su giro objetivo. En Barría, M. (coord.). Estudios de Derecho Civil XI (pp. 439-449). Santiago de Chile: Thomson Reuters.

Barrientos, J. (2014). Código Civil. Edición concordada con observaciones históricas, críticas, dogmáticas yjurisprudenciales.

Tomo I. Santiago de Chile: LegalPublishing - Thomson Reuters. 
Carnelutti, F. (1927). Lezioni di diritto industriale: Teoria del regolamento collettivo dei rapporti di lavoro. Padova: Dott. A. Milani.

Corral, H. (2007). La descodificación del derecho civil en Chile. En Guzmán, A. (ed.). El Código Civil de Chile (18552005) (pp. 641-651). Santiago de Chile: LexisNexis.

Corral, H. (2018). Curso de derecho civil. Parte general. Santiago de Chile: Thomson Reuters.

Cruz, J. (2015). Compendio de derecho del trabajo (8 ed.). Madrid: Editorial Tecnos.

Despax, M. (1966). Traité de droit du travail. Conventions collectives. Publié sous la Direction de G.H. Camerlynck. Paris: Librairie Dalloz.

Díaz, J. (1982). Legislación social. Código del Trabajo. Tomo XXII. Santiago de Chile: Editorial Cepet.

D’Ors, A. (1989). Una introducción al estudio del derecho. Valparaíso: Ediciones Universitarias de Valparaíso.

Ducci, C. (2006). Interpretación jurídica. En general y en la dogmática chilena (reimpresión de la $3^{\text {a }}$ ed.). Santiago de Chile: Editorial Jurídica de Chile.

Escribar, H. (1944). Tratado de derecho del trabajo. Tomo primero. Santiago de Chile: Empresa Editora Zig - Zag S.A.

Elorriaga, F. (2018). Las reglas sobre interpretación de los contratos en los códigos civiles de Chile y España. En Vidal, Á. (dir.) \& Severin, Gonzalo (ed.). Estudios de derecho de contratos en homenaje a Antonio Manuel Morales Moreno (pp. 407-444). Santiago de Chile: Thomson Reuters.

Fernández, R. (2013). Procedencia de las cláusulas tácitas en los instrumentos colectivos. Estudios Laborales. Revista de la Sociedad Chilena de Derecho del Trabajo y de la Seguridad Social, 9, 99-117.

Ferrante, Alfredo (2016). Entre derecho comparado y derecho extranjero. Una aproximación a la comparación jurídica. Revista Chilena de Derecho, 43 (2), 601-618.

Figueroa, G. (2012). Curso de derecho civil. Santiago de Chile: Editorial Jurídica de Chile.

Gaete, A. (1960). Tratado de derecho del trabajo chileno. Santiago de Chile: Editorial Jurídica de Chile.

Gamonal, S. (2020). Derecho colectivo del trabajo (3a ed. actualizada con la ley $N^{\circ}$ 20.940). Santiago de Chile: Der Ediciones.

Gil, L. (1992). Aplicación, administración e interpretación de los convenios colectivos. En Cuadernos de Derecho Judicial. La negociación colectiva. Vol. III. Madrid: Consejo General del Poder Judicial.

Guzmán, A. (1993). Codificación, descodificación y recodificación del derecho civil chileno. Revista de Derecho y Jurisprudencia, tomo XC, No 1, 38-62.

Guzmán, A. (2007). Las reglas del "Código Civil" de Chile sobre interpretación de las leyes (2a ed. revisada). Santiago de Chile: Legal Publishing.

Humeres, H. (1960). Apuntes de derecho del trabajo. Santiago de Chile: Editorial Jurídica de Chile.

Humeres, H. (2005). Derecho del trabajo y de la seguridad social. Tomo II. Derecho colectivo del trabajo ( $17^{\mathrm{a}} \mathrm{ed}$. ampliada y actualizada). Santiago de Chile: Editorial Jurídica de Chile.

Iglesias, M. (1988). La interpretación del Convenio Colectivo. Documentación Laboral, 26, 73-100.

Irureta, P. (2016). El instrumento colectivo en la reforma laboral de 2016. Revista Chilena de Derecho del Trabajo y de la Seguridad Social, 7, (14), 13-37.

Lanata, G. (2011). El derecho civil en el derecho del trabajo. Rosario: Tesis doctoral Universidad de Rosario, Argentina (inédita).

Lanata, G. (2018). Sindicatos y negociación colectiva. Santiago de Chile: Thomson Reuters.

Lizama, L. (1998). La Dirección del Trabajo: una explicación de su facultad de interpretar la legislación laboral chilena. Santiago de Chile: Universidad de Chile, Facultad de Derecho.

Lizama, L. \& Riquelme, G. (2021). Manual de derecho colectivo del trabajo. Santiago de Chile: Der Ediciones.

López, J. (2010). Los contratos. Parte general (5ª ed. actualizada por Fabián Elorriaga de Bonis). Santiago de Chile: Legal Publishing. 
Macchiavello, G. (1989). Derecho colectivo del trabajo. Teoría y análisis de sus normas. Santiago de Chile: Editorial Jurídica de Chile.

Mangarelli, C. (2014). Aplicación supletoria del derecho civil en el derecho del trabajo (1ª reimpresión). Montevideo: Fundación de Cultura Universitaria.

Martín, A.; Rodríguez-Sañudo, F. \& García, J. (2016). Derecho del trabajo (25ª ed.). Madrid: Editorial Tecnos.

Montoya, A. (1997). Aplicación del convenio colectivo. Impugnación y denuncia. En De Buen, N. \& Morgado, E. (coords.). Instituciones de derecho del trabajo y de la seguridad social (pp. 127-137). México D.F.: Academia lberoamericana de Derecho del Trabajo y de la Seguridad Social - Universidad Nacional Autónoma de México.

Montoya, A. (2007). La interpretación del convenio colectivo (apuntes de derecho comparado). Revista del Ministerio de Trabajo e Inmigración, №68, julio de 2007, pp. 101-112. Recuperado de: https://vlex.es/source/revista-mtinministerio-trabajo-inmigracion-41/issue_nbr/\%2368 [fecha de consulta: 10 de agosto de 2021].

Montoya, A. (2019). Derecho del trabajo (40ª ed.). Madrid: Editorial Tecnos.

Moreno, A. Artículo 91: Aplicación e interpretación del convenio colectivo. En Goerlich, J.M. (coord.). En AA.W. Comentarios al Estatuto de los Trabajadores. Libro homenaje a Tomás Sala Franco (pp. 1075-1085). Valencia: Tirant Lo Blanch.

Novoa, P. (1996). Reflexiones sobre la naturaleza jurídica del contrato colectivo. Revista Laboral Chilena, julio de 1996, 55-63.

Ogalde, J. (2016). Modificaciones introducidas en la ritualidad del procedimiento de negociación colectiva reglada en la empresa. En Arellano, P.; Severin, J.P. \& Feres. M.E. (eds.). Reforma al derecho colectivo del trabajo. Examen crítico de la ley N²0.940 (pp. 161-193). Santiago de Chile: Thomson Reuters.

Casas, M.E. \& Olea, M.A. (2000). Validez, impugnación, aplicación e interpretación del convenio colectivo (arts. 90 y 91). Ejemplar dedicado al Estatuto de los Trabajadores. Veinte años después. Revista Española de Derecho del Trabajo, 100, (2), 1579-1599.

Pérez, C. (1937). El contrato colectivo de trabajo. Santiago de Chile: Talleres Gráficos Gutenberg.

Plá, A. (2015). Los principios del derecho del trabajo (4ª ed. al cuidado de Hugo Barretto Ghione). Montevideo: Fundación de Cultura Universitaria.

Real Academia Española (2020). Diccionario de la lengua española. Recuperado de: https://dle.rae.es/ [fecha de consulta: 10 de agosto de 2021].

Rodríguez, P. (1992). Teoría de la interpretación jurídica. Santiago de Chile: Editorial Jurídica de Chile.

Ruiz de Gamboa, A. \& Díaz, J. (1942). Legislación social. Código del Trabajo. Tomo I. Santiago de Chile: Editorial Nascimiento.

Sala, T. (2020). Derecho sindical (3ª ed.). Valencia: Tirant Lo Blanch.

Squella, A. (2008). Introducción al derecho. Santiago de Chile: Editorial Jurídica de Chile.

Tapia, M. (2005). Código Civil 1855-2005. Evolución y perspectivas. Santiago de Chile: Editorial Jurídica de Chile.

Tarello, G. (2013). La interpretación de la ley. Prólogo de Ricardo Guastini y traducción y nota introductoria de Diego Dei Vecchi. Lima: Palestra Editores.

Thayer, W. \& Novoa, P. (2008). Manual de derecho del trabajo. Generalidades. Derecho colectivo del trabajo. Tomo I (5a ed.). Santiago de Chile: Editorial Jurídica de Chile.

Vergara, A. (2010). El derecho administrativo como sistema autónomo. El mito del Código Civil como "Derecho Común". Santiago de Chile: AbeledoPerrot.

Vial, V. (2006). Teoría general del acto jurídico (5ª ed.). Santiago de Chile: Editorial Jurídica de Chile.

Walker, F. \& Arellano, P. (2014). Derecho de las relaciones laborales. Un derecho vivo. Santiago de Chile: Librotecnia. Walker, F. (1941). Nociones elementales de derecho del trabajo. Santiago de Chile: Editorial Nascimiento. 


\section{Jurisprudencia citada}

Administrativa

DIRECCIÓN DEL TRABAJO. (1992, 7 de diciembre). Ord. 7120/331.

DIRECCIÓN DEL TRABAJO. (1996, 24 de julio). Ord. № 4224/172.

DIRECCIÓN DEL TRABAJO. (1997, 17 de junio). Ord. № 3558/193.

DIRECCIÓN DEL TRABAJO. (1998, 30 de julio). Ord. 3496/267.

DIRECCIÓN DEL TRABAJO. (2000, 1 de diciembre). Ord. № 5109/345.

DIRECCIÓN DEL TRABAJO. (2002, 24 de julio). Ord. № 2374.

DIRECCIÓN DEL TRABAJO. (2004, 31 de agosto). Ord. 3988/156.

DIRECCIÓN DEL TRABAJO. (2004, 21 de diciembre). Ord. 5318/206.

DIRECCIÓN DEL TRABAJO. (2014, 6 de octubre). Ord. № 3787.

DIRECCIÓN DEL TRABAJO. (2016, 3 de junio). Ord. № 2996.

DIRECCIÓN DEL TRABAJO. (2017, 27 de junio). Ord. № 2858/79.

DIRECCIÓN DEL TRABAJO. (2018, 11 de junio). Ord. № 2661.

DIRECCIÓN DEL TRABAJO. (2018, 21 de junio). Ord. № 2781.

DIRECCIÓN DEL TRABAJO. (2018, 20 de diciembre). Ord. № 6456.

DIRECCIÓN DEL TRABAJO. (2019, 25 de febrero). Ord. № 734.

DIRECCIÓN DEL TRABAJO. (2019, 10 de septiembre). Ord. № 4355.

DIRECCIÓN DEL TRABAJO. (2020, 5 de febrero). Ord. Nㅜ 676.

Judicial

CORTE SUPREMA (2002, 14 de noviembre). Rol N²209-2002.

CORTE SUPREMA. (2013, 14 de octubre). RUJ (rechazado). Rol № 4187-2013.

CORTE DE APELACIONES DE SANTIAGO. (2012, 17 de agosto). Rol N 120-2012 (Reforma Laboral).

CORTE DE APELACIONES DE SANTIAGO. (2014, 16 de abril). Rol N 1645-2013 (Reforma Laboral).

CORTE DE APELACIONES DE VALPARAÍSO. (2014, 17 de octubre). Rol № 50-2014. (Cobranza).

CORTE DE APELACIONES DE SANTIAGO. (2014, 4 de diciembre), Rol N 334-2014 (Reforma Laboral).

CORTE DE APELACIONES DE RANCAGUA. (2017, 24 de enero). Rol N²04-2016.

CORTE DE APELACIONES DE IQUIQUE. (2017, 16 de marzo). Rol № 7-2017 (Reforma Laboral).

CORTE DE APELACIONES DE SAN MIGUEL. (2017, 7 de diciembre). Rol № 362-2017 (Reforma Laboral).

CORTE DE APELACIONES DE RANCAGUA. (2019, 23 de diciembre). Rol № 268-2019 (Reforma Laboral).

JUZGADO DE LETRAS, GARANTÍA Y FAMILIA DE PEUMO. (2019, 12 de agosto). RIT 0-11-2019.

JUZGADO DE LETRAS DEL TRABAJO DE IQUIQUE. (2016, 30 de diciembre). RIT 0-548-2016.

$1^{\circ} \mathrm{JUZGADO}$ DE LETRAS DEL TRABAJO DE SANTIAGO. (2017, 21 de abril). RIT O-6865-2016.

$2^{\circ}$ JUZGADO DE LETRAS DEL TRABAJO DE SANTIAGO. (2017, 26 de mayo). RIT 0-552-2017.

$1^{\circ}$ JUZGADO DE LETRAS DEL TRABAJO DE SANTIAGO. (2018, 22 de noviembre). RIT S-14-2018.

JUZGADO DE LETRAS DEL TRABAJO DE COPIAPÓ. (2019, 29 de marzo). RIT O-285-2018.

$2^{\circ}$ JUZGADO DE LETRAS DEL TRABAJO DE SANTIAGO. (2020, 12 de marzo). RIT O-4200-2019.

JUZGADO DE LETRAS DEL TRABAJO DE TALCA. (2021, 22 de marzo). RIT S-1-2020. 


\section{Roberto Cerón Reyes}

Judicial extranjera

SENTENCIA DEL TRIBUNAL SUPREMO (España) 717/2019. (2019, 22 de octubre). Sala de lo Social. № de recurso 195/2018.

SENTENCIA DEL TRIBUNAL SUPREMO (España) 713/2019. (2019, 15 de octubre). Sala de lo Social. № de recurso $195 / 2018$.

SENTENCIA DEL TRIBUNAL SUPREMO (España) 5583/2015. (2015, 2 de diciembre). Sala de lo Social. № de recurso 365/2014.

SENTENCIA DEL TRIBUNAL SUPREMO (España) 5597/2015. (2015, 2 de diciembre). Sala de lo Social. № de recurso $68 / 2015$.

SENTENCIA DEL TRIBUNAL SUPREMO (España) 7211/1994. (1994, 8 de noviembre). Sala de lo Social. Nº de recurso 1096/1994. 